\title{
Protein glycation and drought response of pea (Pisum sativum L.) root nodule proteome: a proteomics approach
}

\section{Julia Shumilina1,2, Daria Gorbach¹, Veronika Popova1,3, Alexander Tsarev ${ }^{1,2}$, Alena Kusnetsova ${ }^{1,2}$, Maria Grashina1, Mandy Dorn², Elena Lukasheva', Natalia Osmolovskaya ${ }^{3}$, Ekaterina Romanovskaya1, Vladimir Zhukov ${ }^{4}$, Christian Ihling 5 , Tatiana Grishina1, Tatiana Bilova ${ }^{2,3}$, and Andrej Frolov ${ }^{1,2}$}

${ }^{1}$ Department of Biochemistry, Faculty of Biology, Saint Petersburg State University, Srednii pr., 41-43, Saint Petersburg, 199004, Russian Federation

${ }^{2}$ Department of Bioorganic Chemistry, Leibniz Institute of Plant Biochemistry, Weinberg 3, Halle/Saale, 06120, Germany

${ }^{3}$ Department of Plant Physiology and Biochemistry, Faculty of Biology,

Saint Petersburg State University, Universitetskaya nab., 7-9, Saint Petersburg,

199034, Russian Federation

${ }^{4}$ Department of Biotechnology, All-Russia Research Institute for Agricultural Microbiology,

Shosse Podbel'skogo, 3, Saint Petersburg, 190608, Russian Federation

${ }^{5}$ Department of Pharmaceutical Chemistry and Bioanalytics, Institute of Pharmacy,

Martin-Luther University Halle-Wittenberg, Halle, 06120, Germany

Address correspondence and requests for materials to Andrej Frolov, afrolov@ipb-halle.de

\section{Abstract}

Because of ongoing climate change, drought is becoming the major factor limiting productivity of all plants, including legumes. As these protein-rich crops form symbiotic associations with rhizobial bacteria — root nodules - they readily lose their productivity under drought conditions. Understanding the underlying molecular mechanisms might give access to new strategies to preserve the productivity of legume crops under dehydration. As was shown recently, development of drought response is accompanied by alterations in the patterns of protein glycation and formation of advanced glycation end products (AGEs) that might be a part of unknown regulatory mechanisms. Therefore, here we address the effects of moderate drought on protein dynamics and AGE patterns in pea (Pisum sativum) root nodules. For this, plants inoculated with rhizobial culture were subjected to osmotic stress for one week, harvested, the total protein fraction was isolated from root nodules by phenol extraction, analyzed by bottom-up LC-MS-based proteomics, and AGE patterns were characterized. Surprisingly, despite the clear drought-related changes in phenotype and stomatal conductivity, only minimal accompanying expressional changes (14 rhizobial and 14 pea proteins, mostly involved in central metabolism and nitrogen fixation) could be observed. However, 71 pea and 97 rhizobial proteins (mostly transcription factors, $A B C$ transporters and effector enzymes) were glycated, with carboxymethylation being the major modification type. Thereby, the numbers of glycated sites in nodule proteins dramatically decreased upon stress application. It might indicate an impact of glycation in regulation of transport, protein degradation, central, lipid and nitrogen metabolism. The data are available at Proteome Xchange (accession: PXD024042).

Keywords: advanced glycation end products (AGEs), drought stress, glycation, pea (Pisum sativum), polyethylene glycol (PEG), proteomics, root nodules

\section{Introduction}

Due to the growing impact of ongoing climate change on crop productivity, the mechanisms behind drought tolerance of terrestrial plants are in the focus of modern biology. Indeed, the short-term alterations in daily temperatures are increasing, whereas the amount of precipitation has been continuously decreasing 


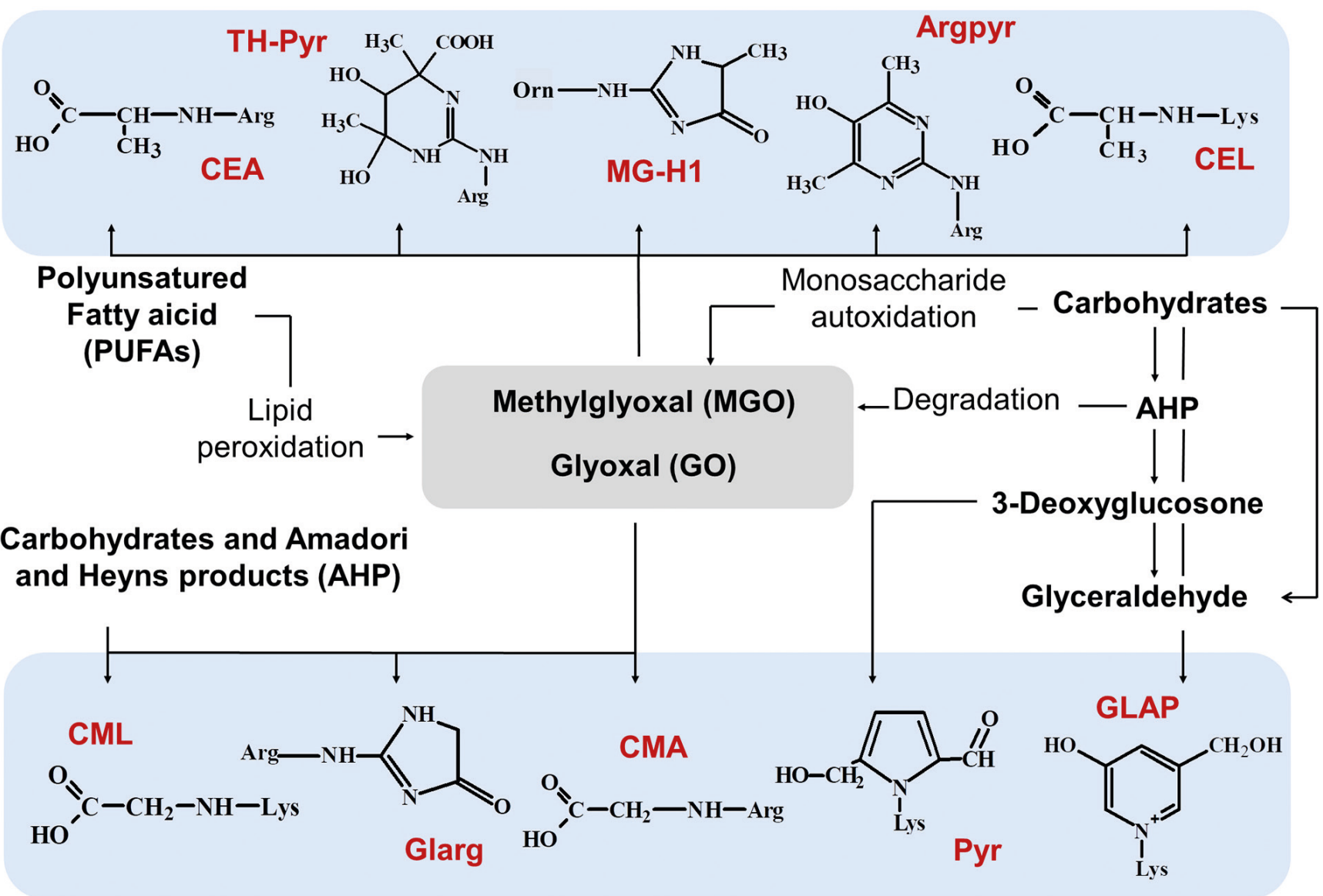

Fig. 1. Advanced glycation end products (AGEs), their precursors and intermediates in the context of underlying formation mechanisms. Abbreviations: CML, $N^{\varepsilon}$-(carboxymethyl)-lysine; CEL, $N^{\varepsilon}$-(carboxyethyl)lysine; CEA, $N^{\delta}$-(carboxyethyl)arginine; CMA, $N^{\delta}$-(carboxymethyl)arginine; Glarg, glyoxal-derived hydroimidazolone; MG-H1, methylglyoxal-derived hydroimidazolone 1 ( $N^{\delta}$-(5-methyl-4-oxo-5-hydroimidazolinone-2-yl)I-ornithine); Argpyr, argpyrimidine; TH-Pyr, tetrahydropyrimidine; Pyr, pyrraline; GLAP, glyceraldehyde-derived pyridinium compound; MOLD, methylglyoxal-derived lysine-lysine imidazolium cross-link; DOLD, 3-deoxyglucosone-derived lysine-lysine imidazolium cross-link.

during recent decades (Ummenhofer and Meehl, 2017). In general, drought can be defined as a form of abiotic stress, characterized by a decrease of water potential and directly impacting the functions of plant tissues and organs, resulting in growth inhibition and drop of leaf turgor and water metabolism (Osmolovskaya et al., 2018). At the level of cell molecules, the plant stress response is accompanied by an array of adaptive reactions, which affect photosynthesis machinery, primary and secondary metabolism, protein dynamics and patterns of posttranslational modifications (PTMs, Verslues et al., 2006).

Plant response to drought is a multi-step process, including both systemic and cell-specific reactions (Bilova et al., 2016a). In the first steps of the plant response, dehydration avoidance (i.e., an array of reactions aimed at reducing water loss) represents the preferred strategy, whereas development of drought tolerance is more characteristic for advanced stages of the drought stress response (Osmolovskaya et al., 2018). Indeed, even moderate dehydration results in stomata closure, overload of electron transport chains, enhanced generation of reactive oxygen species (ROS) and development of oxidative stress (Lushchak, 2011). On the other hand, the drought tolerance strategy assumes accumulation of osmoprotectors - mostly amino acids and reducing sugars (Paudel et al., 2016).

The developing oxidative stress in parallel with the accumulation of drought-related sugar osmolytes triggers carbohydrate autoxidation and lipid peroxidation resulting in the generation of reactive intermediates ( $a$-dicarbonyls and hydroxycarbonyls, Paudel et al., 2016; ALjahdali and Carbonero, 2019). Both reducing sugars and reactive carbonyl compounds readily react with free amino groups of proteins - the phenomenon known as protein glycation (Fig. 1). Reducing sugars yield Amadori and Heyns products (Bilova et al., 2016a), whereas reactive carbonyls directly form advanced glycation end products (AGEs, ALjahdali and Carbonero, 2019; Shumilina et al., 2019).

Although formation, metabolism and biological effects of AGEs are well-studied in animals and humans (Szoke and Gerich, 2005; Uribarri et al., 2005; Soboleva et al., 2017a, b), the role of the Maillard protein adducts in plants still remains mostly unknown, although intensively 
studied (Rabbani et al., 2020). Recently, the dynamics of protein-bound AGEs was characterized not only in leaves (Frolov et al., 2018), but also in seeds (Smolikova et al., 2020) and nodules of legumes (Matamoros et al., 2018). The role of protein glycation in drought-related metabolic shifts and nutritional properties of mature pea seeds (P.sativum) was addressed (Leonova et al., 2020). Besides, multiple alterations in AGE patterns of Arabidopsis thaliana leaf proteins in response to drought were reported (Bilova et al., 2016b; Paudel et al., 2016). However, the changes in root proteome and, especially, in such specialized and metabolically diverse structures as root nodules, have not yet been addressed. Therefore, to fill this gap, here we characterize the changes in pea root proteome, and, specifically, AGE proteome, accompanying the response of these root structures to short-term osmotic stress.

\section{Material and methods}

\section{Reagents, plant material and rhizobial culture}

Unless stated otherwise, materials were obtained from the following manufacturers: AMRESCO LLC (Fountain Parkway Solon, USA): ammonium persulfate (ACS grade), glycine (biotechnology grade), tris(hydroxymethyl)aminomethane (tris, ultra-pure grade); Carl Roth $\mathrm{GmbH}$ \& Co (Karlsruhe, Germany): ammonia solution (25\%); sodium dodecyl sulfate (SDS, $>99 \%$ ), sodium chloride (p.a.), sodium phosphate dibasic dehydrate (p.a.), polyethylene glycol (PEG) 8000 (p.a.), tris-(2-carboxyethyl) phosphine hydrochloride (TCEP, $\geq 98 \%$ ), $\mathrm{MgSO}_{4 \times} 7 \mathrm{H}_{2} \mathrm{O}$ (extra pure); Macherey-Nagel GmbH \& Co KG (Düren, Germany): $\quad N$-methyl- $N$-(trimethylsilyl)trifluoroacetamide (MSTFA, MS grade), Chromabond $\mathrm{C}_{18}$ polypropylene cartridges, $3 \mathrm{~mL}$; Reachem (Moscow, Russia): isopropanol (reagent grade); SERVA Electrophoresis $\mathrm{GmbH}$ (Heidelberg, Germany): Coomassie Brilliant Blue G-250, 2-mercaptoethanol (research grade), NB sequencing grade modified trypsin from porcine pancreas; Thermo Fisher Scientific (Waltham, USA): PageRuler ${ }^{\text {Tx }}$ Prestained Protein Ladder \#26619 (10-250 kDa). All other chemicals were purchased from Helicon (Moscow, Russia). Water was purified in house on a water conditioning and purification system Millipore Milli-Q Integral 3 system (Merck Millipore, Darmstadt, Germany).

Pea seeds of the cultivar SGE and rhizobial culture (Rizobium leguminosarum bv. viciae CIAM 1026) were from the collection of the All-Russia Research Institute of Agricultural Microbiology (St. Petersburg, Russia).

\section{Plant experiments}

Pea seeds were stratified at $4{ }^{\circ} \mathrm{C}$ for two days and germinated at $18^{\circ} \mathrm{C}$ for a further two days in the dark. Afterwards, the seeds were transferred to vermiculite filled in
$1 \mathrm{~L}$ pots and inoculated with rhizobial culture (Rhizobium leguminosarum bv. viciae CIAM 1026). For this, $20 \mathrm{~mL}$ of bacterial culture (OD $=0.3$ un. at $620 \mathrm{~nm} /$ optical path length $1 \mathrm{~cm}$ ) were 100 -fold diluted with water. Afterwards, $150 \mathrm{~mL}$ of diluted bacterial culture were supplemented to each vessel with vermiculite $(\mathrm{V}=1.2 \mathrm{~L})$. The plants were grown at $16 \mathrm{~h} \mathrm{light} / 8 \mathrm{~h}$ dark regimen at $24^{\circ} \mathrm{C}$ under $75 \%$ relative humidity. On the $19^{\text {th }}$ day after inoculation, the plants $(n=6)$ were transferred to a hydroponic system (described in detail by Bilova et al., 2016b), i.e., to aerated aqueous nutritional medium with 5-20\% (w/v) polyethylene glycol 8000 solution (PEG 8000). The control plants $(n=6)$ were transferred to a PEG-free medium. The medium contained $0.041 \mathrm{~mol} / \mathrm{L} \mathrm{MgSO}_{4} \times 7 \mathrm{H}_{2} \mathrm{O}$, $0.06 \mathrm{~mol} / \mathrm{L} \mathrm{K}_{2} \mathrm{HPO}_{4}, 6.5 \mathrm{mmol} / \mathrm{L} \mathrm{Ca}_{3}\left(\mathrm{PO}_{4}\right)_{2}, 0.81 \mathrm{mmol} / \mathrm{L}$ $\mathrm{H}_{3} \mathrm{BO}_{3}, \quad 0.25 \mathrm{mmol} / \mathrm{L} \quad\left(\mathrm{NH}_{4}\right)_{2} \mathrm{MoO}_{4}, \quad 0.05 \mathrm{mmol} / \mathrm{L}$ $\mathrm{KBr}, 0.024 \mathrm{mmol} / \mathrm{L} \mathrm{CuSO}_{4}{ }^{*} 5 \mathrm{H}_{2} \mathrm{O}, 0.03 \mathrm{mmol} / \mathrm{L} \mathrm{KI}$, $0.0045 \mathrm{mmol} / \mathrm{L} \quad \mathrm{Al}_{2}\left(\mathrm{SO}_{4}\right)_{3}{ }^{\star} 18 \mathrm{H}_{2} \mathrm{O}, \quad 0.05 \mathrm{mmol} / \mathrm{L}$ $\mathrm{NaCl}, 0.0124 \mathrm{mmol} / \mathrm{L} \mathrm{MnSO}_{4} * 5 \mathrm{H}_{2} \mathrm{O}, 0.007 \mathrm{mmol} / \mathrm{L}$ $\mathrm{ZnSO}_{4}{ }^{\star} 7 \mathrm{H}_{2} \mathrm{O}, 0.013 \mathrm{mmol} / \mathrm{L} \mathrm{NiSO}_{4}, 0.27 \mathrm{mmol} / \mathrm{L}$ $\mathrm{NaFeEDTA}, \mathrm{pH}=7.2$. After seven days of treatment, the nodules were harvested, i.e., rinsed with water, frozen in liquid nitrogen and ground in a Mixer Mill MM 400 ball mill with a $20 \mathrm{~mm}$ stainless steel ball (Retsch, Haan, Germany) at the vibration frequency of $30 \mathrm{~Hz}$ for $1 \mathrm{~min}$. The ground material was stored at $80^{\circ} \mathrm{C}$ until analysis.

\section{Characterization of drought stress}

The plant response to osmotic stress was assessed by alteration of stomatal conductivity and lipid peroxidation. Stomatal conductivity was assessed with a portable porometer (SC-1 Leaf Porometer, ICT International, Australia) as described before (Leonova et al., 2020). Lipid peroxidation was assessed by accumulation of thiobarbituric acid-reactive substances, which were quantified as malondialdehyde equivalents (MDA) (see Chantseva et al., 2019).

\section{Protein isolation}

The analysis of the pea root nodule proteome relied on the nanoLC-MS-based bottom-up proteomics approach (see Matamoros et al., 2018) with minor modifications. Briefly, for phenol extraction, approximately 60-100 mg of frozen material were transferred to a $2-\mathrm{mL}$ polypropylene tube and supplemented with $700 \mu \mathrm{L}$ of cold $\left(4^{\circ} \mathrm{C}\right)$ phenol extraction buffer $(0.7 \mathrm{~mol} / \mathrm{L}$ sucrose, $0.1 \mathrm{~mol} / \mathrm{L}$ $\mathrm{KCl}, 5 \mathrm{mmol} / \mathrm{L}$ ethylenediaminetetraacetic acid (EDTA), $2 \%(\mathrm{v} / \mathrm{v})$-mercaptoethanol and $1 \mathrm{mmol} / \mathrm{L}$ phenylmethylsulfonyl fluoride (PMSF) in $0.5 \mathrm{~mol} / \mathrm{L}$ tris- $\mathrm{HCl}$ buffer, $\mathrm{pH}$ 7.5). All manipulations were performed at $4^{\circ} \mathrm{C}$. The samples were vortexed for $30 \mathrm{~s}$, and $700 \mu \mathrm{L}$ of cold phenol $\left(4^{\circ} \mathrm{C}\right)$ saturated with $0.5 \mathrm{~mol} / \mathrm{L}$ Tris- $\mathrm{HCl}$ buffer $(\mathrm{pH} 7.5)$ were added. Afterwards, the samples were incubated on 
a vertical rotation platform $\left(30 \mathrm{rpm}, 30 \mathrm{~min}, 4^{\circ} \mathrm{C}\right)$ and centrifuged $\left(2500 \mathrm{~g}, 30 \mathrm{~min}, 4^{\circ} \mathrm{C}\right)$. The upper phenolic phases were transferred to new $2 \mathrm{~mL}$ polypropylene tubes and washed two times with equal volumes of the phenol extraction buffer with vortexing (30 s), shaken $\left(30 \mathrm{rpm}, 30 \mathrm{~min}, 4^{\circ} \mathrm{C}\right.$ ) and centrifuged $(2500 \mathrm{~g}, 15 \mathrm{~min}$, $4^{\circ} \mathrm{C}$ ) after each buffer addition. Finally, the phenolic phases were transferred to new $1.5 \mathrm{~mL}$ safe-lock polypropylene tubes, supplemented with five volumes of cold $\left(-20^{\circ} \mathrm{C}\right) 0.1 \mathrm{~mol} / \mathrm{L}$ ammonium acetate in methanol, and kept at $-20^{\circ} \mathrm{C}$ overnight. The next morning, the proteins were pelleted by centrifugation ( $15 \mathrm{~min}, 2500 \mathrm{~g}, 4^{\circ} \mathrm{C}$ ). The pellets were washed twice with two volumes of cold $\left(-20^{\circ} \mathrm{C}\right)$ methanol (compared to the phenol phase volume), and once with cold acetone (with centrifugation at each step $-2500 \mathrm{~g}, 10 \mathrm{~min}, 4^{\circ} \mathrm{C}$ ). The final pellets were dried under air flow under the hood for $1 \mathrm{~h}$. The protein pellets were reconstituted in $100 \mu \mathrm{L}$ of shotgun buffer $(8 \mathrm{~mol} / \mathrm{L}$ urea, $2 \mathrm{~mol} / \mathrm{L}$ thiourea in $0.1 \mathrm{~mol} / \mathrm{L}$ Tris- $\mathrm{HCl}$ buffer, $\mathrm{pH}$ 7.5) containing $0.1 \%(\mathrm{w} / \mathrm{v})$ anionic acid-labile surfactant II (AALS II). The protein concentrations were determined by the Bradford assay and validated by SDSpolyacrylamide gel electrophoresis (PAGE) as described earlier (Greifenhagen et al., 2016).

\section{Tryptic digestion}

For tryptic digestion, the aliquots of the total nodule protein fraction $(50 \mu \mathrm{g})$ were supplemented with $50 \mathrm{mmol} / \mathrm{L}$ aq. ammonium acetate buffer to obtain a final volume of $90 \mu \mathrm{L}$. Then, $10 \mu \mathrm{L}$ of $50 \mathrm{mmol} / \mathrm{L}$ tris (2-carboxyethyl) phosphine was added, and the resulting mixtures were incubated for $30 \mathrm{~min}$ at $37^{\circ} \mathrm{C}$ in an orbital shaker ( $450 \mathrm{rpm}$ ). After cooling the sample to room temperature, $11 \mu \mathrm{L}$ of $100 \mathrm{mmol} / \mathrm{L}$ of iodoacetamide were added, and the mixtures were incubated for $1 \mathrm{~h}$ at $4^{\circ} \mathrm{C}$. Afterwards, $875 \mu \mathrm{L}$ of $50 \mathrm{mmol} / \mathrm{L}$ ammonium bicarbonate were added. Two aliquots of trypsin $(2.5$ and $1.3 \mu \mathrm{g})$ were supplemented sequentially at the enzyme-protein ratio of 1:20 and 1:40 to the diluted samples, and digestion was accomplished at $37^{\circ} \mathrm{C}$ under continuous shaking ( $450 \mathrm{rpm}$ ) for 5 and $12 \mathrm{~h}$ (overnight), respectively. The digestion efficiency was verified by SDS-PAGE according to the procedure described by Greifenhagen et al. (2016). After decomposition of ALLS $\left(1 \% \mathrm{v} / \mathrm{v} \mathrm{TFA}, 20 \mathrm{~min}\right.$ at $\left.37^{\circ} \mathrm{C}\right)$, the resulted digests were pre-cleaned by reversed phase solid phase extraction (RP-SPE) using the elution scheme of Spiller et al., (2017) and in-house packed StageTips as described by Mamontova et al. (2018).

\section{LC-MS experiments}

Individual tryptic digests ( $500 \mathrm{ng}, 10 \mu \mathrm{L}$ ) dissolved in $3 \%$ (v/v)acetonitrilein $0.1 \%(\mathrm{v} / \mathrm{v})$ aq. TFA wereloaded onto an Acclaim PepMap 100 C18 trap column $(300 \mu \mathrm{m} \times 5 \mathrm{~mm}$,
$3 \mu \mathrm{m}$ particle size) for $15 \mathrm{~min}$ at the flow rate of $30 \mu \mathrm{L} / \mathrm{min}$. Peptides were separated at the flow rate of $300 \mathrm{~nL} / \mathrm{min}$ on an Acclaim PepMap 100C18 column $(75 \mu \mathrm{m} \times 250 \mathrm{~mm}$, particle size $2 \mu \mathrm{m}$ ) using an Ultimate 3000RSLC nanoHPLC system coupled on-line to an OrbitrapXL mass spectrometer via a nano-ESI source equipped with a $30 \mu \mathrm{m}$ ID, $40 \mathrm{~mm}$ long steel emitter (all Thermo Fisher Scientific, Bremen, Germany). The eluents A and B were $0.1 \%(\mathrm{v} / \mathrm{v})$ aq. FA and $0.08 \%(\mathrm{v} / \mathrm{v})$ aq. FA in acetonitrile, respectively. The peptides were eluted with linear gradients ramping from $1 \%$ to $35 \%$ B over $90 \mathrm{~min}$, followed by $35 \%$ to $85 \%$ eluent B over $5 \mathrm{~min}$. The column was washed for $5 \mathrm{~min}$, and re-equilibrated at $1 \%$ eluent B for $10 \mathrm{~min}$. The nano-LC-Orbitrap-MS analysis relied on data-dependent acquisition (DDA) experiments performed in the positive ion mode, comprising a survey Orbitrap-MS scan and dependent MS/MS scans for the most abundant signals in the following $5 \mathrm{~s}$ (at certain $t_{R}$ ), with charge states ranging from 2 to 6 . The spectra were acquired in the $\mathrm{m} / \mathrm{z}$ range of $300-1500$ with the mass resolution of 120,000 in the positive ion mode. The ion spray voltage was $1900 \mathrm{~V}$, S-lens voltage was $20 \mathrm{~V}$, ion transfer tube temperature was $275^{\circ} \mathrm{C}$. The MS/MS spectra were acquired in the data-dependent acquisition (DDA) mode with the mass resolution of 15000 , using high-energy collision dissociation (HCD) functionality (27\% relative collision energy) with the isolation width of $2 \mathrm{~m} / \mathrm{z}$. Dynamic exclusion was applied for $60 \mathrm{~s}$ with the width of $\pm 2 \mathrm{ppm}$. The raw data are available on the Proteome Xchange platform as the project "Proteins of Pisum sativum nodules (LC-MS/MS)" (project accession: PXD024042; DOI: 10.6019/PXD024042).

\section{Processing and post-processing of the proteomics data}

The spectra were searched against the pea (Kreplak et al., 2019) and rhizobial (Rhizobium leguminosarum bv. Viciae, Afonin et al., 2017) sequence databases with SEQUEST engine operated in the framework of the Proteome Discoverer 2.1 software (Thermo Fisher Scientific, Bremen, Germany). Seven AGE-related modifications $N^{e}$-(carboxymethyl)lysine/arginine (CML/CMA, $+58.01 / \mathrm{K}, \mathrm{R}), \quad N^{\varepsilon}$-(carboxyethyl)lysine/arginine (CEL/ CEA, 72.0211/K,R), glyceraldehyde-derived pyridinium adduct (GLAP, +109.029/K), glyoxal (+39.995/R), and methylglyoxal (54.011/R)-derived hydroimidazolones (Glarg and MG-H, respectively), as well as oxidation of methionine and tryptophan $(+15.995 / \mathrm{M}, \mathrm{W})$, di-, trioxidation of tryptophan $(+31.99 / \mathrm{W}$ and $+47.985 / \mathrm{W}$, respectively) and kynurenin $(+3.995 / \mathrm{W})$ - were selected as variable modifications, whereas cysteine carbamidomethylation $(+57.021)$ was selected as the fixed one. Label-free relative quantification relied on the Progenesis QIP (Waters, Eschborn, Germany) and Proteome 

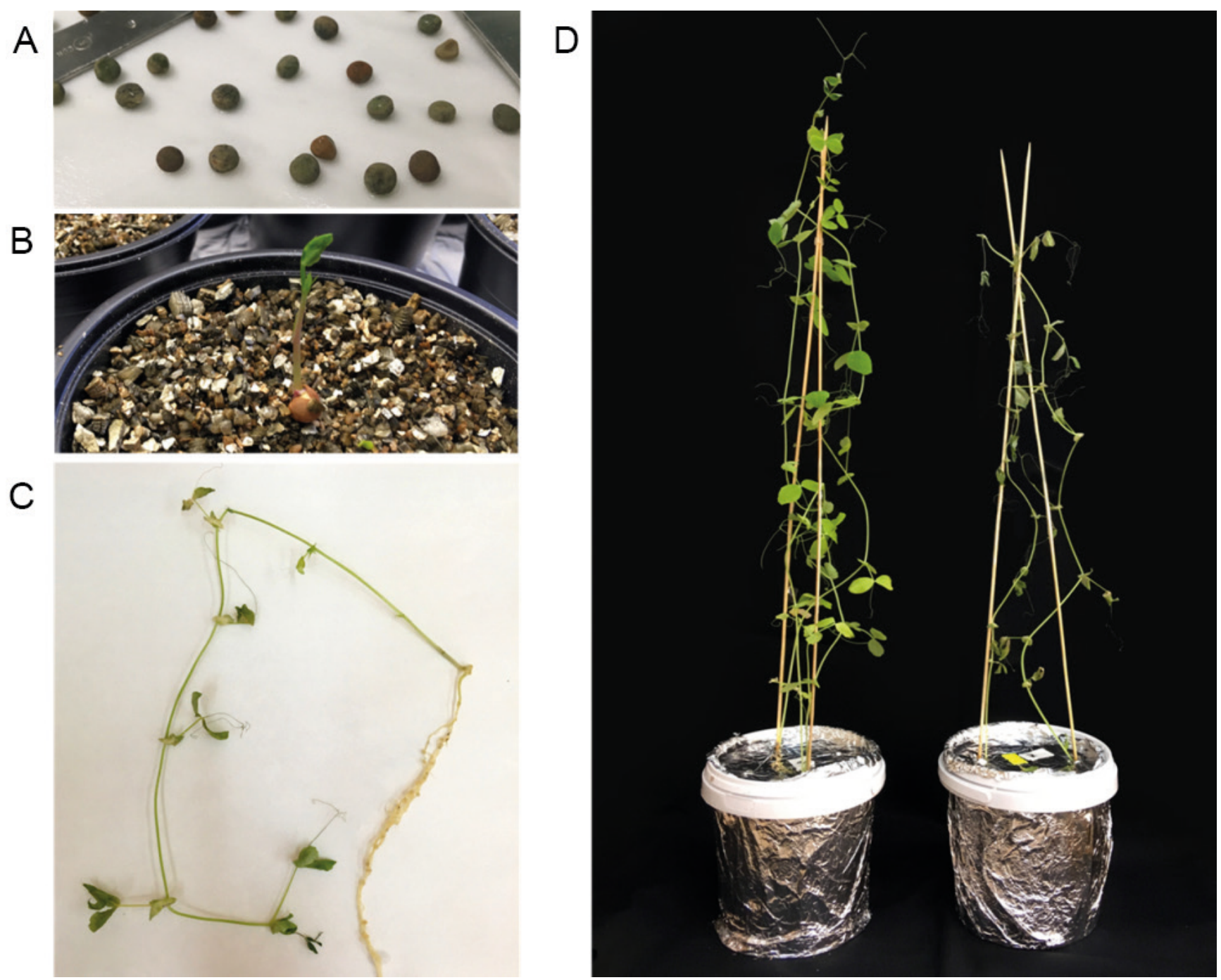

Fig. 2. Cultivation of pea (P. sativum) plants: germinating seeds (A), seedlings (B), two-week-old plants prior stress application (C), 30-day-old drought-treated (right) and control (left) plants prior to harvesting (D).

Discoverer 2.0 (Thermo Fisher Scientific, Bremen, Germany) softwares. Settings for label-free quantification (LFQ): $\max \mathrm{CV}<60.5$, fold.change $>1.5$, adjusted $p$-value $\leq 0.1$, q-value $\leq 0.1$. Data post-processing was performed in the statistical programming environment $\mathrm{R}$ ( $\mathrm{R}$ version - 4.0.2, packages: limma, Biobase, topGO, KEGGREST, pheatmap, VennDiagram), data annotation relied on well-established online tools (Mercator MapMan, Blast KOALA for KEGG ontology, BUSCO for cellular localization). Protein interactions were analyzed using String database (Szklarczyk et al., 2017).

\section{Results}

\section{Establishment of drought stress}

The seeds (Fig. 2A) germinated quantitatively and produced healthy seedlings during the first week of the experiment. All seedlings were successfully transferred to vermiculite pots immediately after completion of ger- mination. No abnormalities in plant development were found after a week of growth on vermiculite (Fig. 2B), before the plants were successfully transferred to the hydroponic system (Fig. 2C, D). No visible difference in morphology of individual plants could be observed before stress application (supplementation of PEG 8000 in the growth medium). However, the drought-treated (i.e., subjected to osmotic stress) plants showed the first signs of dehydration - loss of leaf turgor, chlorosis and necrosis (Fig. 2C) already on the second day after drought application. Interestingly, roots and nodules of control and experimental plants did not show any visible differences.

\section{Stress characterization}

At the first step, in the series of optimization experiments, the stress dosage was adjusted to yield moderate stress severity. For this, two-week-old plants were transferred to the aerated pots with growth medium supplemented with 5, 10, 15 and $20 \%$ (w/v) PEG 8000 and were grown 

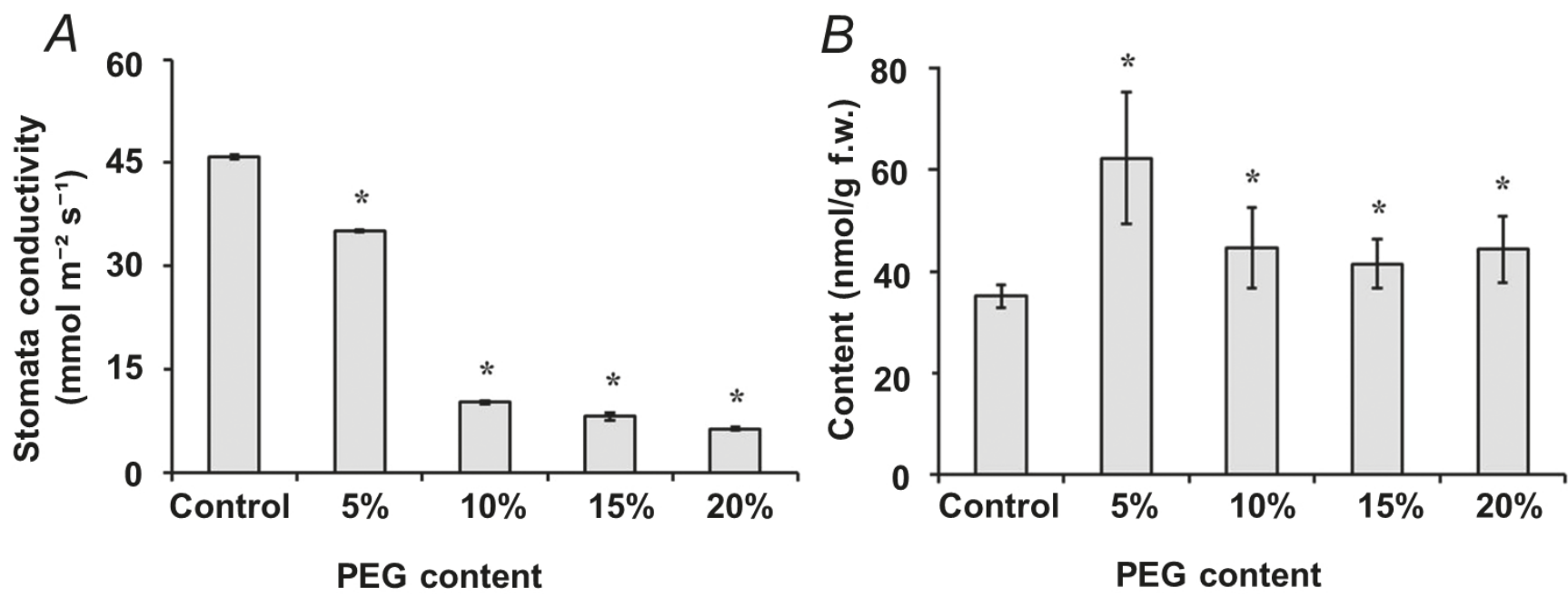

Fig. 3. Characterization of the stress response in pea ( $P$. sativum) plants by stomatal conductivity (A) and contents of TBA-reactive substances (expressed as MDA equivalents, B). The plants were grown at $16 \mathrm{~h}$ light/ $8 \mathrm{~h}$ dark regimen at $24^{\circ} \mathrm{C}$ under $75 \%$ relative humidity on vermiculite. On the $19^{\text {th }}$ day after inoculation the plants $(n=6)$ were transferred to the hydroponic system containing 5-20\% (w/v) polyethylene glycol 8000 solution (PEG 8000). *Differences were statistically significant ( $p \leq 0.05$ ), as was determined by the Mann-Whitney U-test.

for a further week. The supplementation of $5 \%(\mathrm{w} / \mathrm{v}) \mathrm{PEG}$ resulted in a slight (approximately $22 \%$ ), but significant $(p \leq 0.05)$ drop of stomatal conductivity (Fig. 3A). Further increase of the PEG content in growth medium resulted in progressing suppression of transpiration, manifested with up to six-fold reduction of stomatal conductivity, when the highest concentration of the polymer was applied. The observed stress-related drop of stomatal conductivity was accompanied by an increase in leaf contents of TBA-reactive substances (Fig. 3B). Thus, 5\% (w/w) PEG caused minimal drought stress in pea, whereas $10 \%(\mathrm{w} / \mathrm{w})$ resulted in moderate stress. Therefore, for proteomics experiments, osmotic stress was established by supplementation of $10 \%(\mathrm{w} / \mathrm{w})$ PEG to the culture medium to simulate moderate drought.

\section{Protein isolation and tryptic digestion}

The total protein fraction was successfully isolated from the pea nodules by the phenol extraction procedure. The protein concentrations were in the range of $0.87-$ $2 \mathrm{mg} / \mathrm{mL}$, whereas the yields were in the range of 9.2$159.3 \mathrm{mg} / \mathrm{g}$ fresh weight (Table S1-1) ${ }^{1}$. The precision of protein determination was estimated by SDS-PAGE. For this, $5 \mu \mathrm{g}$ of each protein sample (calculated based on the results of the Bradford assay) were loaded on parallel lanes (Fig. S1-1A). The whole lane average intensities demonstrated relatively low variability, as could be judged by relative standard deviation ( $\mathrm{RSD}=7.3 \%)$. The protein samples were successfully hydrolyzed by trypsin - the proteolysis was quantitative, as no bands could

${ }^{1}$ Supplemental material to the article is available at https://biocomm.spbu.ru/article/view/10086 be seen when SDS-PAGE was performed with tryptic digests (Fig. S1-1B).

\section{Analysis of protein dynamics in root nodules in response to osmotic stress}

In total, 862 plant (Fig. 4A) and 582 rhizobial (Fig. 4B) non-redundant proteins were identified by MS/MS spectra in pea root nodules (Supplementary information 2, Tables S2-1 and S2-2). These proteins were represented by 2734 and 2352 individual peptides corresponding to 1830 and 596 possible individual polypeptides, respectively (Fig. S1-2 and S1-3, Tables S2-3-S2-6). Identification of peptide sequences relied on tandem mass spectrometry (MS/MS) in DDA experiments. However, it needs to be taken into account that drought-specific annotation of proteins by DDA-MS/MS can be related to the intensity bias or intrinsic restrictions of the method. Due to this well-known limitation of the DDA algorithm (usually referred to as undersampling, Mamontova et al., 2018), the differences in the patterns of protein identification obtained in DDA experiments need to be confirmed by the label-free quantification (LFQ) approach.

Indeed, label-free relative quantification of protein abundance profiles revealed only minimal differences between drought-treated and control groups. Thus, only five pea nodule proteins were up-regulated and nine were down-regulated (Table 1), i.e., only 14 of 862 identified pea proteins ( $1.6 \%$ of annotated pea nodule proteome) could be confirmed as affected by osmotic stress. As the numbers of differentially expressed proteins were low, we increased the confidence level from $p \leq 0.05$ to $p \leq 0.1$. The up-regulated proteins were involved in central metabolism (fructose-bisphosphate aldolase and malate dehydro- 
$\boldsymbol{A}$

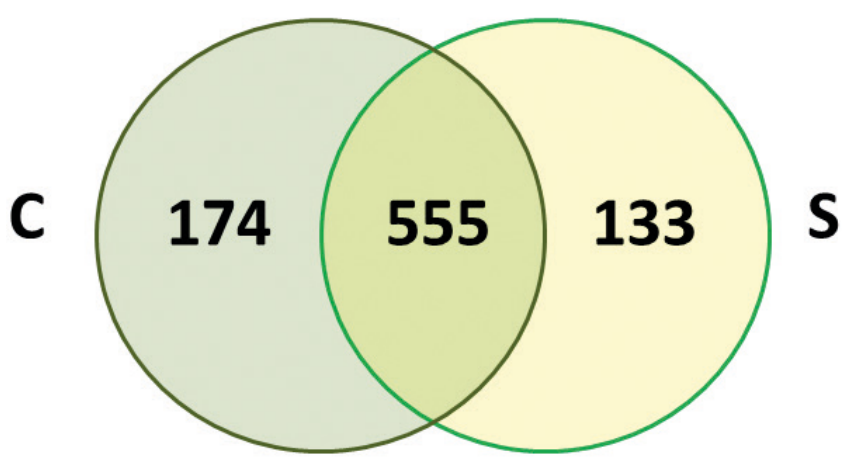

B

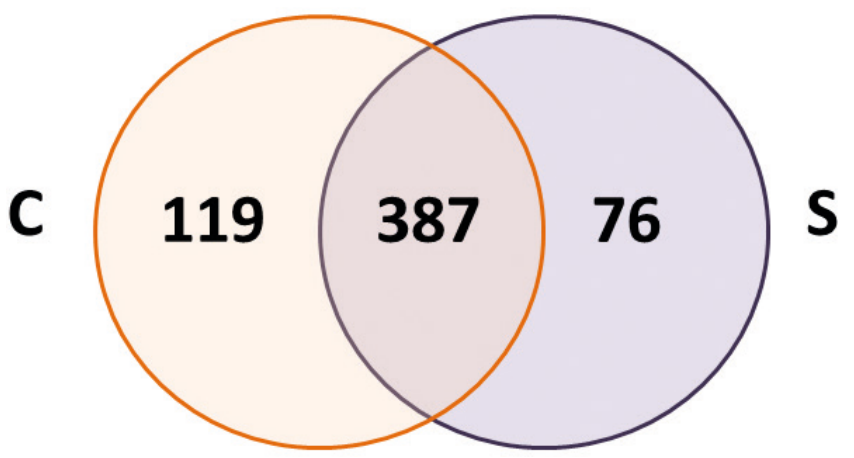

Fig. 4. Non redundant pea $(A)$ and rhizobial $(B)$ proteins identified in the root nodules of the control (C) and stress-treated pea (S) (P. sativum) plants. The database search relied on pea ( $P$. sativum, Kreplak et al 2019) and rhizobial (R. leguminosarum, Afonin et al., 2017) sequence database in Proteome Discoverer 2.1.

genase), nitrogen fixation (leghemoglobin) and Golgi to plasma membrane protein transport (Golgin subfamily A member 4-like protein). On the other hand, the most pronounced down-regulation (three-fold) was observed for S-adenosylmethionine synthase and pathogenesis-related protein 10b, involved in abscisic acid signaling. Most of the other down-regulated plant proteins were involved in protein synthesis (ribosomal structure) and folding (Table 1). For all differentially abundant proteins the MS/MS spectra were manually verified (Figs. S1-4 and S1-5). Thereby, about $20-24 \%$ of all polypeptides were identified by MS/ MS solely in nodule protein isolates from drought-treated plants (Fig. 4A, B), although the corresponding signals could be detected at the MS level in all treatment groups.

Surprisingly, a similar quantitative result was observed for the rhizobial nodule proteome. In this case, five proteins were up-regulated and nine were down-regulated upon application of osmotic stress (Table 2). The up-regulated proteins were mostly involved in regulatory processes - phosphorylation, dephosphorylation and interaction with DNA (transcriptional activatior A0A1Q8HJ66 and nucleoside diphosphate kinase). Further polypeptides were involved in nitrogen (amino acid ABC transporter substrate-bindnig protein) and energy metabolism (glycerol-3-phospha- tase and malate dehydrogenase). Down-regulation was less pronounced in the bacterial symbiotic partner - all changes were within a two-fold span. Similar to the plant proteome, the pathways of central energy and nitrogen metabolism were suppressed. Nitrogen fixation was the main function down-regulated in the rhizobial proteome: not only were nitrogenase and nitrogenase molybdenum iron protein affected, but also glutamate metabolism (succinatesemialdehyde dehydrogenase and 4-aminobutyrate transaminase) was suppressed and the involvement of glutamate in protein synthesis was blocked (Table 2).

\section{Analysis of non-enzymatic posttranslational protein modifications in root nodules in response to osmotic stress}

Glycation of nodule proteins was assessed by characteristic marker modifications, derived from the major glycation intermediates, characterized in our previous work (Bilova et al., 2016b; Paudel et al., 2016). Thereby, mono-, di-, trioxidation of tryptophan and kynurenin were considered here as oxidative modifications, whereas glyceraldehyde-derived pyridinium compound (GLAP), $N^{\varepsilon}$-(carboxymethyl)- and $N^{\varepsilon}$-(carboxyethyl) lysine (CML and CEL, respectively), glyoxal- and methylglyoxal-derived hydroimidazolones (Glarg and MG$\mathrm{H}$, respectively) were selected as the major plant AGEs. The modifications of plant and rhizobial nodule proteins were searched against both the pea and rhizobial sequence databases (Supplementary information 3).

\section{Patterns of glycation and oxidation in the pea nodule proteome}

The search against pea sequence database altogether revealed 90 glycated peptides, representing in total 71 proteins, whereas 48 peptides in 38 proteins were oxidized by tryptophan residues. Surprisingly, the search revealed a dramatic (37\% overall) decrease in AGE identification rates after one-week exposure to osmotic stress in comparison to untreated controls (Fig. S1-6A). Tryptophan oxidative modifications were less represented, although in the relative scale, the drop of the oxidative modification number upon stress application was comparable (Fig. S1-6B). Among AGEs, CML and CMA formed the most representative group (37 peptides, Fig. 5A). Interestingly, half of these proteins (19 entries) were not detected as modified in stressed plants. Carboxymethylated proteins represented several functional groups, dominated with regulatory kinases, transcription factors, effector enzymes and cytoskeleton. Glyceraldehyde 3-phosphate kinase was strongly glycated (CML-modified), and characteristic glycation site was represented by two peptides. Carboxymethylation also affected E3 ubiquitin-protein ligase RNF185 and ABC transporter STD2 (Table S3-1). All of the other glycative modifications 
A

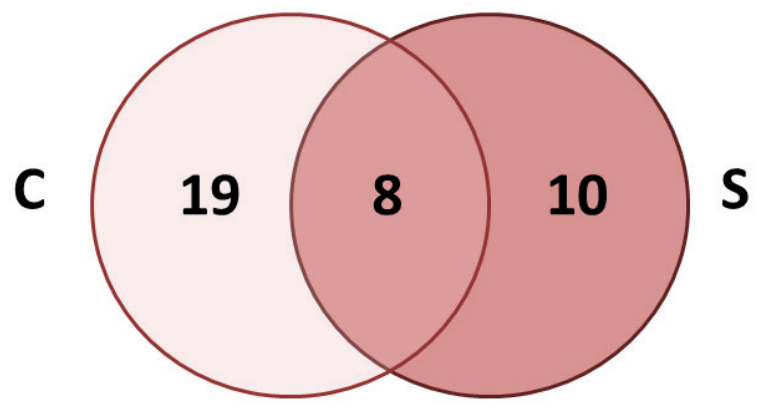

C

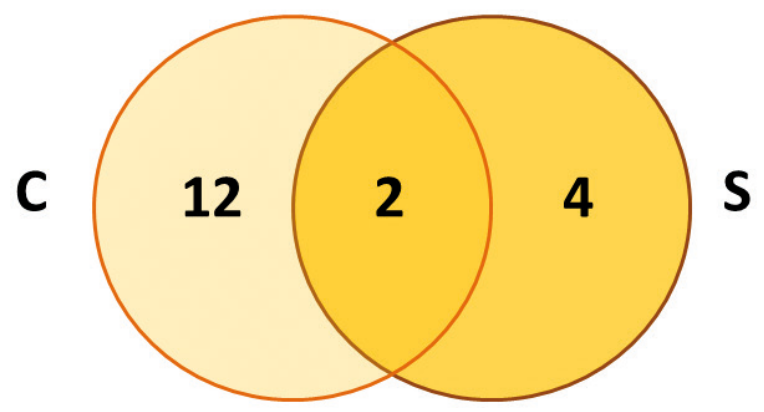

B

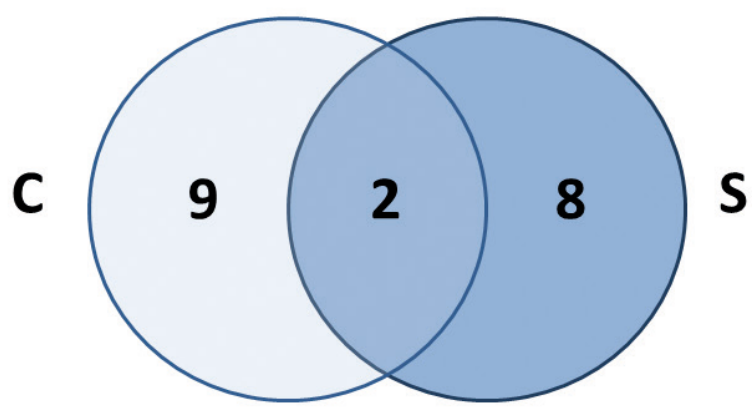

D

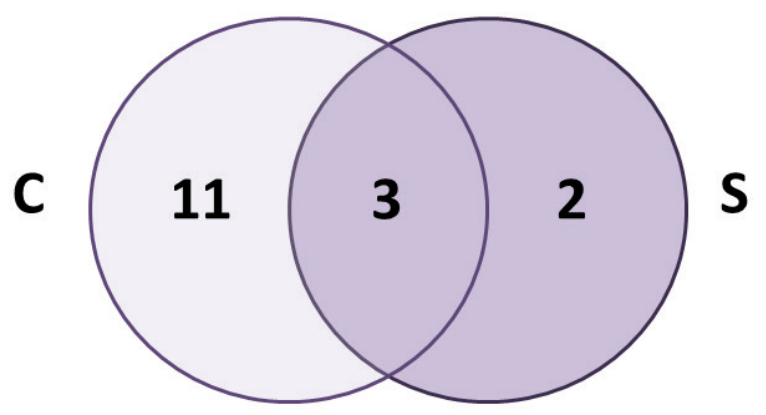

Fig. 5. Numbers of individual glycated peptides, containing $N^{\varepsilon}$-(carboxymethyl)lysine and $N^{\varepsilon}$-(carboxyethyl)lysine (CML and CEL, A), glyceraldehyde-derived pyridinium compound (GLAP, B), glyoxal-derived hydroimidazolone (Glarg, C) and methylglyoxal-derived hydroimidazolone (MG$H, D$ ) residues, and identified by nanoLC-MS-based proteomics analysis of pea ( $P$. sativum) nodule protein tryptic digests obtained from control (C) and PEG-treated (stressed, S) plants. The data were acquired by nanoHPLC-LIT-Orbitrap-MS operated in the positive DDA mode. Identification of glycated peptides and annotation of glycated proteins relied on Sequest search against pea $(P$. sativum) sequence database (Kreplak et al., 2019) in Proteome Discoverer 2.1 software with implementation of characteristic modification-specific increments.

were two-fold less abundant in site occupancy under stress conditions (Fig. 5B-D), although some functional aspects of their patterns attract special attention. Thus, an important enzyme of cell wall biosynthesis was strongly modified with GLAP, whereas MG-H glycation patterns included DNA-binding proteins (Tables S3-2, S3-4).

Oxidation of tryptophan was widely represented in pea nodule proteome with single oxidation strongly dominating (20 vs 11,5 and 12 doubly, triply oxidated and kinurenine-containing peptides, respectively, Figs. S1-6A-C, S1-7). Half of this group was detected specifically in the stressed plant. Among these stress-induced oxidative modifications were three sites in leghemoglobines, one site in lipoxygenase and one in alpha- $L$ arabinofuranosidase (Table S3-6). Interestingly, aspartate amino transferase and E3 ubiquitin protein ligase were strongly oxidized by tryptophan residues.

\section{Patterns of glycation and oxidation in rhizobial pea nodule proteome}

The search against the rhizobial sequence database revealed altogether 106 glycated peptides, representing 97 proteins, whereas 50 peptides in 38 proteins were oxidized by tryptophan residues. This search revealed higher numbers of tryptic peptides, annotated as AGEmodified and oxidized, which might indicate higher amenability of rhizobial proteome to non-enzymatic modifications. However, reduction in the occupancy of glycation sites upon stress application was even higher in comparison to the pea part of the nodule proteome $45 \%$ of rhizobial glycation sites could not be detected at the MS/MS level in the nodules of the plants subjected to osmotic stress (Fig. S1-8). In contrast, the difference in the profiles of rhizobial protein oxidation between the control and stress-treated nodules was less striking (Fig. S1-6D-F).

Similar to the plant part of the glycated nodule proteome, carboxymethylation at lysine and arginine residues was the dominating modification and could be detected at 39 sites in different proteins (Fig. S3-9). The two functional groups of proteins most strongly affected by this type of modification were transcription factors and $\mathrm{ABC}$ transporters, although effector enzymes were also found to be intensively glycated. Surprisingly, most of these proteins were found unglycated after application of osmotic stress (Fig. 6A and Table S3-9). The high glycation occupancy in the groups of transporters was 
$\boldsymbol{A}$

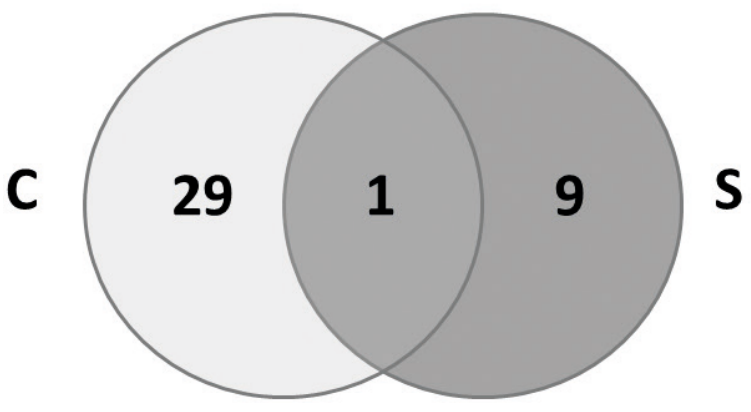

C

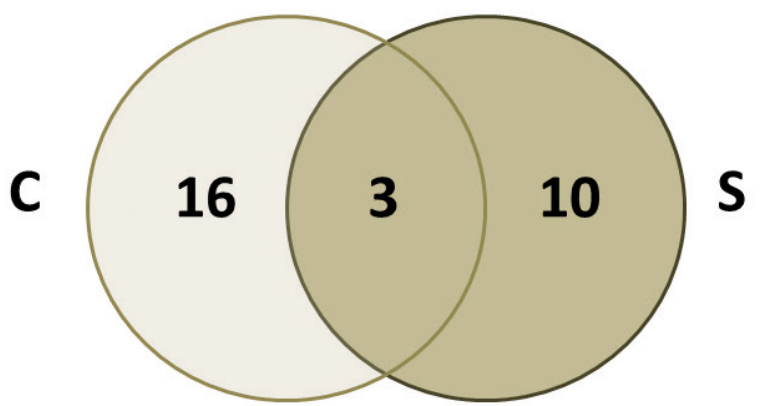

B

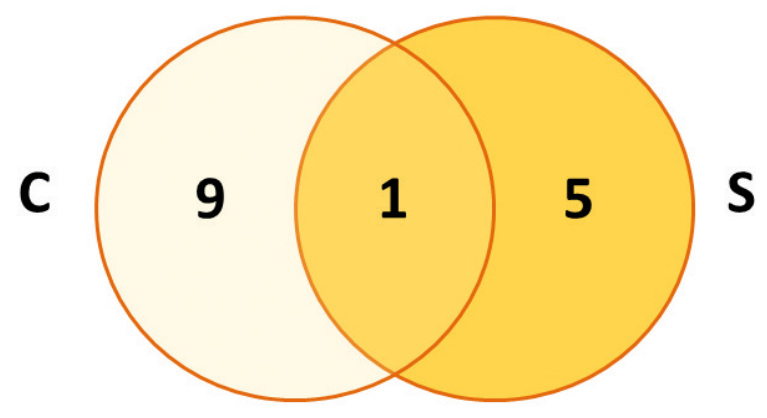

D

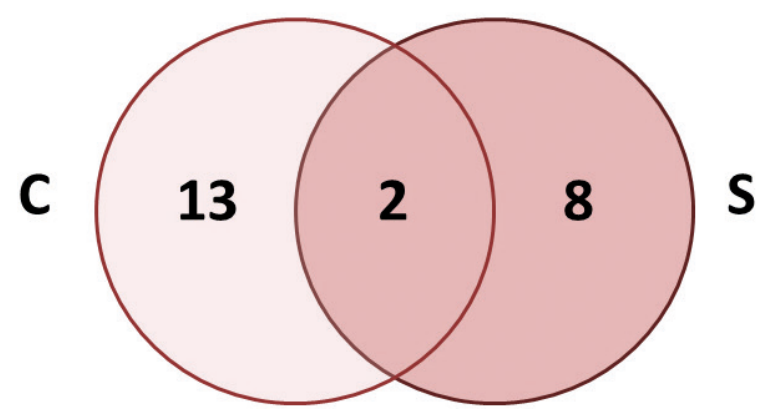

Fig. 6. Numbers of individual glycated peptides, containing $N^{\varepsilon}$-(carboxymethyl)lysine and $N^{\varepsilon}$-(carboxyethyl)lysine (CML and CEL, A), glyceraldehydes-derived pyridinium compound (GLAP, C), glyoxal-derived hydroimidazolone (Glarg, D) and methylglyoxal-derived hydroimidazolone (MG$\mathrm{H}, \mathrm{E})$ residues, and identified by nanoLC-MS-based proteomics analysis of rhizobial ( $R$. leguminosarum) nodule protein tryptic digests obtained from control (C) and PEG-treated (stressed, S) plants. The data were acquired by nanoHPLC-LIT-Orbitrap-MS operated in the positive DDA mode. Identification of glycated peptides and annotation of glycated proteins relied on Sequest search against pea $(P$. sativum) sequence database (Afonin et al., 2017) in Proteome Discoverer 2.1 software with implementation of characteristic modification-specific increments.

also characteristic for other AGEs (Table S3-10, S3-11), although the overall numbers were lower for each of the further (besides CML and CMA) adduct types (Fig. 6B-D).

The rhizobial patterns of protein oxidation were similar to those of the pea part of the nodule proteome (Fig. S1-7). Thereby, single oxydation was the dominating tryptophan modification in the nodule rhizobial proteome, although the occurrence of kynnurenine was higher in comparison to the pea part of the nodule proteome. It can be noticed that nitrogenase, the principal actor in the process of nitrogen fixation, was strongly oxidized (Tables S3-16). The further targets of oxidation were transcription factors, $\mathrm{ABC}$ transporters and enzymes of central metabolism.

\section{Discussion}

Based on our previous experience with application of PEG 8000 in agar infusion and hydroponic models (Frolov et al., 2017; Leonova et al., 2020), we decided for this high-molecular weight osmotically active compound to ensure the absence of plasmolysis and to provide adequate interpretation of the results. For stress characterization, two markers, addressing different aspects of plant response to drought and relying on orthogonal techniques, were employed. Stomatal closure represents an early abscisic acid (ABA)-mediated reaction (Finkelstein, 2013), which was clearly observed in this study already with minimal stress dosage (Fig. 3A). These data corresponded well to the increase of MDA levels due to the development of oxidative stress (Fig. 3B), known to accompany plant response to drought (Osmolovskaya et al., 2018). In order to obtain more pronounced effects (which would be desirable for this proof of concept study) and to avoid artifacts, we decided on moderate drought and rejected minimal osmotic stress as delivering less contrasting differences between treatment and control groups. On the other hand, severe dehydration designs could yield artifacts and were therefore avoided as well.

Surprisingly, the experimental setup applied here revealed only few differentially expressed proteins, 28 altogether in both plant and rhizobial proteomes (Tables 1 and 2), although the overall numbers of identified non-redundant proteins (Fig. 4) were in agreement with the data reported for other legumes and even exceeded the published values (González et al., 2020). This relatively low amount of differentially abundant proteins in comparison to high protein identification rates deter- 
Table 1. Changes in plant protein abundance patterns of pea (Pisum sativum) root nodules associated with osmotic stress

\begin{tabular}{|c|c|c|c|c|c|c|c|}
\hline \multirow{2}{*}{$\begin{array}{l}\text { Protein } \\
\text { dynamics } \\
\text { profile }^{a}\end{array}$} & \multirow[b]{2}{*}{ \# } & \multirow[b]{2}{*}{ Protein ID $^{b}$} & \multirow[b]{2}{*}{ Protein name } & \multirow[b]{2}{*}{ Functional annotation } & \multicolumn{3}{|c|}{ Metrics } \\
\hline & & & & & $\begin{array}{c}\text { fold } \\
\text { change }^{h}\end{array}$ & $p_{1}{ }^{i}$ & $\mathrm{q}_{1}{ }^{k}$ \\
\hline \multirow{5}{*}{$\begin{array}{l}\text { Up- } \\
\text { regulation }\end{array}$} & 1 & A0A2Z6NNA7 & Fructose-bisphosphate aldolase & Glycolytic process & 1.8 & 0.03 & 0.05 \\
\hline & 2 & B7FJQ4 & Malate dehydrogenase & Carbohydrate metabolic process & 1.9 & 0.06 & 0.07 \\
\hline & 3 & P93851 & Leghemoglobin $\mathrm{K}$ & Oxygentransport, nitrogen fixation & 1.6 & 0.009 & 0.05 \\
\hline & 4 & A0A2K3NSTO & Leghemoglobin & Oxygentransport, nitrogen fixation & 1.8 & 0.05 & 0.07 \\
\hline & 5 & A0A2K3MYZ6 & $\begin{array}{l}\text { Golgin subfamily A member 4-like } \\
\text { protein }\end{array}$ & $\begin{array}{l}\text { Golgi to plasma membrane protein } \\
\text { transport }\end{array}$ & 1.2 & 0.07 & 0.07 \\
\hline \multirow{9}{*}{$\begin{array}{l}\text { Down- } \\
\text { regulation }\end{array}$} & 6 & A0A2K3MWHO & S-adenosylmethionine synthase & $\begin{array}{l}\text { S-adenosylmethionine biosynthetic } \\
\text { process }\end{array}$ & 3.1 & 0.02 & 0.05 \\
\hline & 7 & A0A2K3NWF8 & Protein disulfide-isomerase & Protein disulfide isomerase activity & 1.4 & 0.07 & 0.07 \\
\hline & 8 & A0A1S2YB61 & Serine hydroxymethyltransferase & Glycine biosynthetic process from serine & 1.8 & 0,04 & 0.05 \\
\hline & 9 & B7FMK4 & $40 S$ ribosomal protein $\mathrm{S} 24$ & Translation & 2.2 & 0.01 & 0.05 \\
\hline & 10 & A0A396JGV3 & Putative ribosomal protein $\mathrm{L7}$ & Maturation of LSU-rRNA/RNA transcript & 1.9 & 0.02 & 0.05 \\
\hline & 11 & A0A1S2Y9D8 & Aminopeptidase & Metallopeptidase activity & 1.4 & 0.04 & 0.05 \\
\hline & 12 & A0A2K3NQW3 & Calreticulin & Protein folding & 1.4 & 0.02 & 0.05 \\
\hline & 13 & A0A2P4IHJ4 & Tubulin & Microtubule cytoskeleton organization & 1.8 & 0.04 & 0.05 \\
\hline & 14 & K4LMW7 & Pathogenesis-related protein 10b & Abscisic acid-activated signaling pathway & 3.2 & 0.001 & 0.01 \\
\hline
\end{tabular}

${ }^{a}$ protein clustering based on Progenesis QI software and ANOVA one-factor dispersion analysis calculated for integral protein content; ${ }^{b}$ protein annotation was based on sequence database from Uniprot: Pisum sativum; ${ }^{h}$ the change rate (fold change) corresponded to the protein abundance (expression) difference between the stressed and unstressed conditions; ${ }^{i} p$ values (here filtered for adjusted $p \leq 0.1$ ) were obtained with the single-factor ANOVA dispersion analysis using Progenesis QI software; ${ }^{k} \mathrm{q}$ values were obtained with the single-factor ANOVA dispersion analysis using Progenesis QI software.

mined by MS/MS can be explained by two main reasons. On the one hand, due to duty cycle limitations, the DDA algorithm suffers from the well-known phenomenon of undersampling (Mamontova et al, 2019), i.e., less abundant peptides present in all samples are involved in fragmentation only in some of them. On the other hand, reliable label-free quantification (LFQ) protocols are based on at least two peptides, whereas only one confidently identified peptide is sufficient for protein annotation.

Nevertheless, for the bacterial symbiosis partner, the patterns of differential protein abundance were in agreement with the data of Larrainzar et al., obtained with a classical object, Medicago truncatula (2007). Similarly to our work, the authors found the rhizobial enzymes involved in central metabolism and nitrogen fixation down-regulated. Thereby, the numbers of differentially expressed proteins and degree of alterations were similar to our work, where it was maximally two-fold (Table 2). Remarkably, the authors used the stop watering approach, i.e., a completely different drought setup. Thus, the alterations obtained in our work might reflect the general drought-related tendencies common for different legume species and various drought models. Based on the results of the String database analysis, the main tendency might be down-regulation of rhizobial central metabolism. Thereby, malate dehydrogenase played the key role in the observed changes, being the functional link between all other metabolic shifts (Fig. 7). The most remarkable metabolic alteration was the clear suppression of nodule amide metabolism, which is known to be more pronounced in drought-sensitive legume cultivars (Furlan et al., 2017). Here this suppression can be seen at several levels: not only nitrogenase and succinate semialdehyde dehydrogenase enzymes were affected, but also generally energy supply and translation were involved.

In contrast, for plant proteins, striking differences could be seen between our observations for pea nodule proteome and the data obtained by the Wienkoop's group for M. truncatula and P. max (Furlan et al., 2017). Indeed, the proteins \#1-4 in Table 1 (representing central metabolism and nitrogen fixation machinery), found drought-dependently up-regulated here, were strongly expressionally suppressed in $M$. truncatula upon application of water deficit. Interestingly, leghemoglobins were not affected in P. max nodules. Remarkably, although the protein synthesis function was drought-dependently suppressed in all plants, in pea nodules it was represented by other proteins than in ones obtained from 


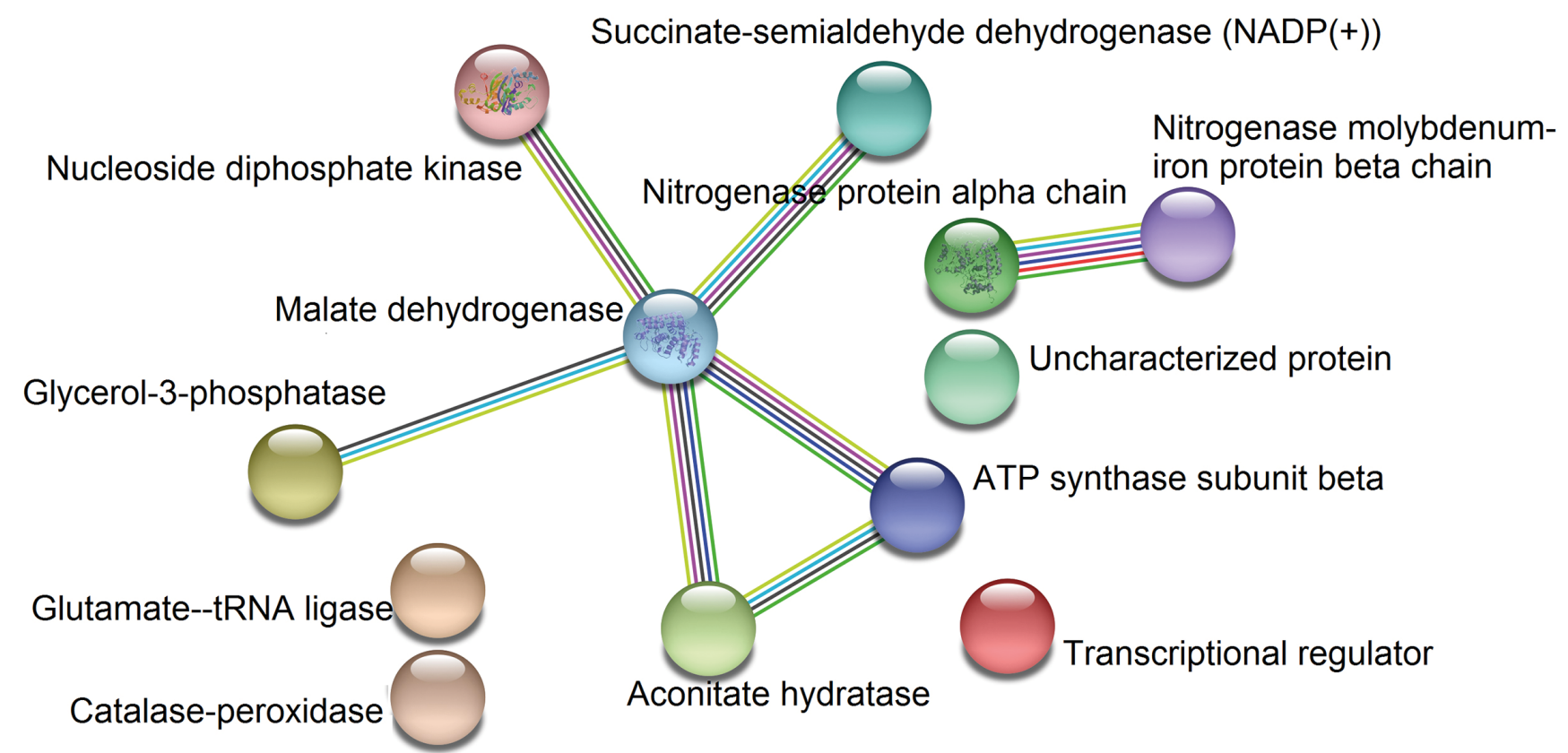

Fig. 7. Network of protein-protein structural and functional relationships between the pea nodule proteins representing Rhizobium leguminosarum bv. viciae proteome. Protein interactions were analyzed using String database (Szklarczyk et al., 2017). The edges indicate both functional and physical protein associations. Line colors indicate the type of interaction evidence: green - gene neighborhood, red - gene fusions, purple - gene co-occurrence, black - co-expression, blue - known interactions from curated databases, pink - experimentally determined interactions, yellow - text mining (co-mentioned in Pubmed abstracts).

M. truncatula. It is known that legume-rhizobial symbiosis changes the proteome patterns of drought stress response (Turetschek et al., 2020). Thus, such changes might be species- and, probably, even cultivar-specific, although the model-related bias of the protein dynamics profiles seems to be the most probable.

Although the response of pea plants to drought was comprehensively characterized recently (Castillejo et al., 2016), the drought-related alterations of pea nodule proteome were described here, to the best of our knowledge, for the first time. Obviously, in future, our results need to be complemented by the data acquired for the same pea cultivar with other drought models. This would allow more reliable conclusions about the origin of the observed inconsistence with the data on plant nodule proteome obtained by the Wienkoop's group.

At the next step, we addressed the nodule protein glycation patterns and their alterations in response to drought. Here we selected specific lysine- and argininederived AGEs, which proved to be characteristic for the leaf of drought-treated Arabidopsis plants (Paudel et al., 2016). As triose phosphates are featured with very high glycation potential (Bilova et al., 2016b), we included glyceraldehyde-derived pyridinium compound (GLAP) in this study as well. In line with earlier published results (Paudel et al., 2016), CML and CMA comprised the most represented AGE group, accounting for 41 and $37 \%$ of glycated peptides identified in the database search against pea and rhizobial fasta files, respectively (Supplementary information 3). In contrast, Glarg and MG-H were the least abundant modifications, accounting for only 20 and $18 \%$ of identified glycated peptides, respectively. This pattern was in agreement with the ratios observed in our previous study with Arabidopsis leaf (Paudel et al., 2016). Thereby, glycated proteins mostly represented enzymes and transcription factors or other regulatory molecules (mostly modified at arginine residues, Tables S3-1-4). Accordingly, Glarg- and MG-H-modified proteins were mostly represented by the polypeptides interacting with nucleic acids. As hydroimidazolone moiety might affect protein $\mathrm{pI}$ and tertiary structure, formation of these AGEs in transcription factors can underlie regulation of corresponding genes.

Recently, Chaplin et al. published a list of Arabidopsis leaf proteins glycated under stress conditions (2019). However, most of them were not detected here. It can be explained by species and (more probably) organ/tissue specificity of this list. Interestingly, some proteins matching to the list of the Bechtold's group, like glyceraldehyde-3-phosphate dehydrogenase, were found in control samples, but some sites were not observed under drought conditions (Table S3-1). Interestingly, lipoxygenase was found glycated in Bechtold's study and oxidized here, whereas this enzyme of lipid metabolism was shown to be affected (down-regulated) in M.truncatula nodules under drought conditions (González et 
Table 2. Changes in rhizobial protein abundance patterns of pea (Pisum sativum) root nodules associated with osmotic stress

\begin{tabular}{|c|c|c|c|c|c|c|c|}
\hline \multirow{2}{*}{$\begin{array}{l}\text { Protein } \\
\text { dynamics } \\
\text { profile }^{a}\end{array}$} & \multirow[b]{2}{*}{$\#$} & \multirow[b]{2}{*}{ Protein ID ${ }^{b}$} & \multirow[b]{2}{*}{ Protein name } & \multirow[b]{2}{*}{ Functional annotation } & \multicolumn{3}{|c|}{ Metrics } \\
\hline & & & & & $\begin{array}{c}\text { fold } \\
\text { change }^{h}\end{array}$ & $p_{1}{ }^{i}$ & $\mathbf{q}_{1}{ }^{k}$ \\
\hline \multirow{5}{*}{$\begin{array}{l}\text { Up- } \\
\text { regulation }\end{array}$} & 1 & A0A1Q8HP36 & Glycerol-3-phosphatase & dephosphorylation & 2.2 & 0.008 & 0.05 \\
\hline & 2 & A0A1Q8HNR1 & $\begin{array}{l}\text { Amino acid } A B C \text { transporter } \\
\text { substrate-binding protein }\end{array}$ & nitrogen compound transport & 1.5 & 0.0008 & 0.02 \\
\hline & 3 & A0A1Q8HJ66 & Transcriptional regulator & Transcriptional regulator & 1.2 & 0.16 & 0.16 \\
\hline & 4 & A0A1Q8HKT2 & Nucleoside diphosphate kinase & CTP biosynthetic process & 1.8 & 0.01 & 0.05 \\
\hline & 5 & A0A1Q8HBN9 & Malate dehydrogenase & Carbohydratemetabolicprocess & 1.3 & 0.02 & 0.04 \\
\hline \multirow{9}{*}{$\begin{array}{l}\text { Down- } \\
\text { regulation }\end{array}$} & 6 & A0A1Q8H9E9 & $\begin{array}{l}\text { Succinate-semialdehyde } \\
\text { dehydrogenase }(\operatorname{NADP}(+))\end{array}$ & $\begin{array}{l}\text { gamma-aminobutyric acid catabolic } \\
\text { process }\end{array}$ & 1.6 & 0.01 & 0.05 \\
\hline & 7 & A0A1Q8HBE8 & ATP synthase subunit beta & ATP synthesis & 1.3 & 0.03 & 0.05 \\
\hline & 8 & A0A1Q8HD96 & Uncharacterized protein & Unreviewed & 1.5 & 0.01 & 0.05 \\
\hline & 9 & A0A1Q8H9C5 & 4-aminobutyrate transaminase & Aminotransferase & 1.5 & 0.05 & 0.06 \\
\hline & 10 & A0A1Q8HEV3 & Aconitate hydratase & tricarboxylic acid cycle & 1.5 & 0.05 & 0.07 \\
\hline & 11 & A0A1Q8HJB2 & Catalase-peroxidase & $\begin{array}{l}\text { hydrogen peroxide catabolic process; } \\
\text { response to oxidative stress }\end{array}$ & 1.7 & 0.05 & 0.07 \\
\hline & 12 & A0A1Q8H6F8 & Nitrogenase protein alpha chain & nitrogen fixation & 1.6 & 0.02 & 0.05 \\
\hline & 13 & A0A1Q8HIJ8 & Glutamate-tRNA ligase & glutamyl-tRNAaminoacylation & 1.8 & 0.03 & 0.05 \\
\hline & 14 & A0A1Q8H6F7 & $\begin{array}{l}\text { Nitrogenase molybdenum-iron } \\
\text { protein beta chain }\end{array}$ & nitrogen fixation & 1.4 & 0.01 & 0.05 \\
\hline
\end{tabular}

${ }^{a}$ protein clustering based on Progenesis QI software and ANOVA one-factor dispersion analysis calculated for integral protein content; ${ }^{b}$ protein annotation was based on sequence database from Uniprot: Rhizobium leguminosarum bv. viciae (proteome, unassembled proteome component, Whole Genome Shotgun (WGS)); ${ }^{h}$ the change rate (fold change) corresponded to the protein abundance (expression) difference between the stressed and unstressed conditions; ${ }^{i} p$ values (here filtered for adjusted $p \leq 0.1$ ) were obtained with the single-factor ANOVA dispersion analysis using Progenesis QI software; ${ }^{k} q$ values were obtained with the single-factor ANOVA dispersion analysis using Progenesis QI software.

al., 2020). This aspect needs to be addressed in more detail in future studies with employment of targeted proteomics techniques. Although drought is assumed to accelerate ageing (Munné-Bosch et al., 2001), no match between the proteins identified here and those discovered in our recent study of bean nodule ageing (Matamoros et al., 2018) was observed.

On the other hand, several further important pea nodule proteins were found to be glycated as well. Thus, carboxymethylation of E3 ubiquitin-protein ligase and ubiquitin carboxyl-terminal hydrolase might impact protein degradation. This might give an explanation for lower glycation rates upon stress application. Indeed, glycation of these effector proteins might enhance degradation of (glyc)oxidatively damaged protein in $26 \mathrm{~S}$ proteasome - the mechanism already demonstrated in animal cells (Uchiki et al., 2012), but still not described in plants. Moreover, Moheimani et al. proposed that agedependent decrease in proteasomal activity might be related to formation of carbonyl-derived adducts with active sites of $\beta$-type subunits (2010), although involvement of other players of the proteasomal protein degradation machinery cannot be excluded. Activation of the proteosomal protein degradation pathway can be at least partly controlled by glycation/deglycation events. This can also be an explanation for dramatic drought-related decrease in the numbers of glycation sites: it might indicate enhanced protein turnover rates under stress conditions and accelerated degradation of glycated proteins.

Another interesting group of proteins, found here to be glycated, were transport proteins. For example, ABC transporter (polar-amino-acid-transporting ATPase) and nodulin MtN21/EamA-like transporter family protein could be identified (Tables S3-1-2). Under drought conditions, the first was deglycated and the second one was glycated. Also, cytoskeleton proteins were AGEmodified - villin, tubulin and microtubule-associated TORTIFOLIA-like protein (Tables S3-1-4). Thus, transport function is another aspect prospectively affected by glycation.

Evaluation of the rhizobial glycated proteome revealed strong predominance of metabolic enzymes, transcriptional regulators and transport proteins as the targets of AGE formation. Thereby, many of these proteins were deglycated under stress conditions (Tables S3-9-12). Among the enzymes, the players of the central 
metabolism pathways represented a pronounced group. Thus, glycolytic enzymes triosephosphate isomerase, enolase and glyceraldehyde-3-phosphate dehydrogenase (GPDH), as well as pyruvate dehydrogenase E1 component subunit beta (a part of the pyruvate dehydrogenase complex) were found to be glycated in absence and deglycated (excepting GPDH) upon stress application. Analogously, rhizobial nitrogen metabolism was affected by glycation. Thus, creatinase, amidase and aspartate aminotransferase family protein were deglycated upon drought application, whereas amidohydrolase was glycated under stress conditions.

The AGE-modified transport proteins demonstrated unexpected drought-related dynamics of modification (Tables S3-9-12). Proteins such as peptide ABC transporter substrate-binding protein, $D$-xylose $A B C$ transporter ATP-binding protein, ectoine/hydroxyectoine $\mathrm{ABC}$ transporter $\mathrm{ATP}$-binding protein EhuA, MFS transporter A0A1Q8HMG2, metal ABC transporter permease and multidrug $\mathrm{ABC}$ transporter ATP-binding protein were deglycated under stress conditions. On the other hand, $\mathrm{ABC}$ transporter ATP-binding protein A0A1Q8HHT9, ABC transporter ATP-binding protein A0A1Q8HPS6, sugar ABC transporter permease and efflux pump membrane transporter were up-glycated upon drought application. Finally, only MFS transporter A0A1Q8H6L9 could be detected as glycated droughtindependently. Interestingly, deglycated sites were mostly carboxymethylated in controls, whereas the sites of drought-related glycation were mostly related to hydroimidazolone modifications. Thus, the bacterial data confirm the assumption that glycation might be involved in regulation of membrane transporters. Earlier, we found three rhizobial ABC transporters to be up-glycated during nodule ageing in bean (Matamoros et al., 2018). The glycation response to drought seems to differ from the events accompanying ageing and mostly pronounced as deglycation of the effector molecules.

Considering oxidized proteins, it can be seen that modification of tryptophan residues mostly occurs in catalytically active proteins. Thereby, nitrogen fixation is one of the primary targets for tryptophan oxidation. Indeed, in rhizobia such critically important proteins as NADP-dependent succinate-semialdehyde dehydrogenase, multiple sites in $\alpha$ chain of nitrogenase, $\beta$ chain of molybdenum-iron nitrogenase and aspartate aminotransferase were oxidized. However, these modifications were observed both in stress and control groups and might be, therefore, unrelated to drought.

\section{Conclusion}

Although glycation of plant proteins has been intensively studied over the whole recent decade, it still remains mostly an underexplored area. Recently, the Maillard reaction was shown to be involved in plant response to environmental stress and ageing. Here, to the best of our knowledge, for the first time we report the patterns of glycation in indeterminate nodules of pea. These patterns were different from those we reported earlier for ageing in determinate nodules of common bean (Matamoros et al., 2018). And, in contrast to the ageing process addressed in our earlier works, drought resulted in essential suppression of glycation of nodule proteins, both representing plant and rhizobial proteomes. Moreover, this stress-related deglycation could be demonstrated for several functional classes of proteins (the most pronounced of which were transport, protein degradation, glycolysis and nitrogen metabolism), each represented by multiple accessions. This fact brings us to the assumption that glycation might be involved in stressrelated events in root nodules, which is in line with the hypothesis proposed earlier for glycated leaf proteome of Arabidopsis (Paudel et al., 2016; Chaplin et al., 2019). As the next step, the observed phenomenon needs to be addressed at the quantitative level, using label-free or label-based techniques. For the confirmed hits, experiments with bacterial and/or pea mutants with changed potential glycation sites can be done. The disturbance of regulatory networks by this approach will allow unambiguous proving of this concept.

\section{References}

Afonin, A., Sulima, A., Zhernakov, A., and Zhukov, V. 2017. Draft genome of the strain RCAM1026 Rhizobium leguminosarum bv. viciae. Genom Data 11:85-86. https://doi. org/10.1016/j.gdata.2016.12.003

Aljahdali, N. and Carbonero, F. 2019. Impact of Maillard reaction products on nutrition and health: Current knowledge and need to understand their fate in the human digestive system. Critical Reviews in Food Science and Nutrition 59:474-487. https://doi.org/10.1080/10408398.20 17.1378865

Bilova, T., Greifenhagen, U., Paudel, G., Lukasheva, E., Brauch, D., Osmolovskaya, N., Tarakhovskaya, E., Balcke, G. U., Tissier, A., Vogt, T., Milkowski, C., Birkemeyer, C., Wessjohann, L., and Frolov, A. 2016a. Glycation of plant proteins under environmental stress methodological approaches, potential mechanisms and biological role. Abiotic and Biotic Stress in Plants - Recent Advances and Future Perspectives 12:295-316. https://doi. org/10.5772/61860

Bilova, T., Lukasheva, E., Brauch, D., Greifenhagen, U., Paudel, G., Tarakhovskaya, E., Frolova, N., Mittasch, J., Balcke, G. U., Tissier, A., Osmolovskaya, N., Vogt, T., Wessjohann, L. A., Birkemeyer, C., Milkowski, C., and Frolov, A. 2016b. A Snapshot of the plant glycated proteome: structural, functional and mechanistic aspects. Journal of Biological Chemistry 291:7621-7636. https:// doi.org/10.1074/jbc.M115.678581

Castillejo, M-A., Iglesias-Garcia, R., Wienkoop, S., and Rubiales, D. 2016. Label-free quantitative proteomic analysis of tolerance to drought in Pisum sativum. Proteomics 16:2776-2787. https://doi.org/10.1002/pmic.201600156

Chantseva, V., Bilova, T., Smolikova, G., Frolov, A., and Medvedev, S. 2019. 3D-clinorotation induces specific alterations 
in metabolite profiles of germinating Brassica napus L. seeds. Biological Communications 64(1):55-74 https:// doi.org/10.21638/spbu03.2019.107

Chaplin, A. K., Chernukhin, I., and Bechtold, U. 2019. Profiling of advanced glycation end products uncovers abiotic stress-specific target proteins in Arabidopsis. Journal of Experimental Botany 70:653-670. https://doi. org/10.1093/jxb/ery389

Finkelstein, R. 2013. Abscisic acid synthesis and response. Arabidopsis Book 11:e0166. https://doi.org/10.1199/ tab.0166

Frolov, A., Bilova, T., Paudel, G., Berger, R., Balcke, G. U., Birkemeyer, C., and Wessjohann, L. A. 2017. Early responses of mature Arabidopsis thaliana plants to reduced water potential in the agar-based polyethylene glycol infusion drought model. Journal of Plant Physiology 208:70-83. https://doi.org/10.1016/j.jplph.2016.09.013

Frolov, A., Mamontova, T., Ihling, C., Lukasheva, E., Bankin, M., Chantseva, V., Vikhnina, M., Soboleva, A., Shumilina, J., Mavropolo-Stolyarenko, G., Grishina, T., Osmolovskaya, N., Zhukov, V., Hoehenwarter, W., Sinz, A., Tikhononovich, I., Wessjohann, L., Bilova, T., Smolikova, G., and Medvedev, S. 2018. Mining seed proteome: from protein dynamics to modification profiles. Biological Communications 63(1):43-58. https://doi.org/10.21638/ spbu03.2018.106

Furlan, A. L., Bianucci, E., Castro, S., and Dietz, K.-J. 2017. Metabolic features involved in drought stress tolerance mechanisms in peanut nodules and their contribution to biological nitrogen fixation. Plant Science 263:12-22. https://doi.org/10.1016/j.plantsci.2017.06.009

Gonzalez, E. M., Wienkoop, S., Staudinger, C., Lyon, D., and GilQuintana, E. 2020. Medicago truncatula: local response of the root nodule proteome to drought stress. The Model Legume Medicago truncatula 1096-1101. https://doi. org/10.1002/9781119409144.ch142

Greifenhagen, U., Frolov, A., Buher, M., and Hoffmann, R. 2016. Site-specific analysis of advanced glycation end products in plasma proteins of type 2 diabetes mellitus patients. Analytical and Bioanalytical Chemistry 408:55575566. https://doi.org/10.1007/s00216-016-9651-4

Kreplak, J., Madoui, M.-A., Cápal, P., Novák, P., Labadie, K., Aubert, G., Bayer, P. E., Gali, K. K., Syme, R. A., Main, D., Klein, A., Bérard, A., Vrbová, I., Fournier, C., d'Agata, L., Belser, C., Berrabah, W., Toegelová, H., Milec, Z., Vrána, J., Lee, H., Kougbeadjo, A., Térézol, M., Huneau, C., Turo, C. J., Mohellibi, N., Neumann, P., Falque, M., Gallardo, K., McGee, R., Tar'an, B., Bendahmane, A., Aury, J.-M., Batley, J., Paslier, M.-C.L., Ellis, N., Warkentin, T.D., Coyne, C. J., Salse, J., Edwards, D., Lichtenzveig, J., Macas, J., Doležel, J., Wincker, P., and Burstin, J. 2019. A reference genome for pea provides insight into legume genome evolution. Nature Genetics 51:1411-1422. https:// doi.org/10.1038/s41588-019-0480-1

Larrainzar, E., Wienkoop, S., Weckwerth, W., Ladrera, R., Arrese-Igor, C., and González, E. M. 2007. Medicago truncatula root nodule proteome analysis reveals differential plant and bacteroid responses to drought stress. Plant Physiology 144:1495-1507. https://doi.org/10.1104/ pp.107.101618

Leonova, T., Popova, V., Tsarev, A., Henning, C., Antonova, K., Rogovskaya, N., Vikhnina, M., Baldensperger, T., Soboleva, A., Dinastia, E., Dorn, M., Shiroglasova, O., Grishina, T., Balcke, G. U., Ihling, C., Smolikova, G., Medvedev, S., Zhukov, V. A., Babakov, V., Tikhonovich, I. A., Glomb, M. A., Bilova, T., and Frolov, A. 2020. Does protein glycation impact on the drought-related changes in metabolism and nutritional properties of mature pea (Pisum sati- vum L.) seeds? International Journal of Molecular Sciences 21(2):567. https://doi.org/10.3390/ijms21020567

Lushchak, V. I. 2011. Environmentally induced oxidative stress in aquatic animals. Aquatic Toxicology 101:13-30. https:// doi.org/10.1016/j.aquatox.2010.10.006

Mamontova, T., Lukasheva, E., Mavropolo-Stolyarenko, G., Proksch, C., Bilova, T., Kim, A., Babakov, V., Grishina, T., Hoehenwarter, W., Medvedev, S., Smolikova, G., and Frolov, A. 2018. Proteome map of pea (Pisum sativum L.) embryos containing different amounts of residual chlorophylls. International Journal of Molecular Sciences 19(12):4066. https://doi.org/10.3390/ijms19124066

Matamoros, M. A., Kim, A., Peñuelas, M., Ihling, C., Griesser, E., Hoffmann, R., Fedorova, M., Frolov, A., and Becana, M. 2018. Protein carbonylation and glycation in legume nodules. Plant Physiology 177:1510-1528. https://doi. org/10.1104/pp.18.00533

Moheimani, F., Morgan, P.E., Reyk, D. M., and Davies, M.J. 2010. Deleterious effects of reactive aldehydes and glycated proteins on macrophage proteasomal function: Possible links between diabetes and atherosclerosis. BBA - Molecular Basis of Disease 1802:561-571. https:// doi.org/10.1016/j.bbadis.2010.02.007

Munne-Bosch, S., Jubany-Mari, T., and Alegre, L. 2001. Drought-induced senescence is characterized by a loss of antioxidant defences in chloroplasts. Plant, Cell ans Environment 24:1319-1327. https://doi.org/10.1046/ j.1365-3040.2001.00794.x

Osmolovskaya, N., Shumilina, J., Kim, A., Didio, A., Grishina, T., Bilova, T., Keltsieva, O.A., Zhukov, V., Tikhonovich, I., Tarakhovskaya, E., Frolov, A., and Wessjohann, L.A. 2018. Methodology of drought stress research: experimental setup and physiological characterization. International Journal of Molecular Sciences 19(12):4089. https://doi.org/10.3390/ijms19124089

Paudel, G., Bilova, T., Schmidt, R., Greifenhagen, U., Berger, R., Tarakhovskaya, E., Stöckhardt, S., Balcke, G. U., Humbeck, K., Brandt, W., Sinz, A., Vogt, T., Birkemeyer, C., Wessjohann, L., and Frolov, A. 2016. Osmotic stress is accompanied by protein glycation in Arabidopsis thaliana. Journal of Experimental Botany 67:6283-6295. https://doi. org/10.1093/jxb/erw395

Pickup, J. C. 2004. Inflammation and activated innate immunity in the pathogenesis of type 2 diabetes. Diabetes Care 27:813-823. https://doi.org/10.2337/diacare.27.3.813

Rabbani, N., Al-Motawa, M., and Thornalley, P. J. 2020. Protein glycation in plants-an under-researched field with much still to discover. International Journal of Molecular Sciences 21(11):3942. https://doi.org/10.3390/ijms21113942

Shumilina, J., Kusnetsova, A., Tsarev, A., Janse van Rensburg, H.C., Medvedev, S., Demidchik, V., Van den Ende, W., and Frolov, A. 2019. Glycation of plant proteins: regulatory roles and interplay with sugar signalling? International Journal of Molecular Sciences 20(9):2366. https://doi.org/10.3390/ijms20092366

Smolikova, G., Gorbach, D., Lukasheva, E., Mavropolo-Stolyarenko, G., Bilova, T., Soboleva, A., Tsarev, A., Romanovskaya, E., Podolskaya, E., Zhukov, V., Tikhonovich, I., Medvedev, S., Hoehenwarter, W., and Frolov, A. 2020. Bringing new methods to the seed proteomics platform: challenges and perspectives. International Journal of Molecular Sciences 21(23):9162. https://doi.org/10.3390/ ijms21239162

Soboleva, A., Modzel, M., Didio, A., Plociennik, H., Kijewska, M., Grischina, T., Karonova, T., Bilova, T., Stefanov, V., Stefanowicz, P., and Frolov, A. 2017a. Quantification of prospective type 2 diabetes mellitus biomarkers by stable isotope dilution with bi-labeled standard glycat- 
ed peptides. Analytical Methods 9:409-418. https://doi. org/10.1039/C6AY02483A

Soboleva, A., Schmidt, R., Vikhnina, M., Grishina, T., and FroIov, A. 2017b. Maillard proteomics: opening new pages. International Journal of Molecular Sciences 18(12):2677. https://doi.org/10.3390/ijms18122677

Spiller, T., Schick, M., Schnyder, U., Bryant, R., Nickerson, A., and Morina, N. 2017. Symptoms of posttraumatic stress disorder in a clinical sample of refugees: A network analysis. European Journal of Psychotraumatology 8:1318032. https://doi.org/10.1080/20008198.2017.1318032

Szklarczyk, D., Morris, J., Cook, H., Kuhn, M., Wyder, S., Simonovic, M., Santos, A., Doncheva, N., Roth, A., Bork, P., Jensen, L., and Mering, C. 2017. The STRING Database in 2017: Quality-Controlled Protein-Protein Association Networks, Made Broadly Accessible. Nucleic Acids Research 45(D1):D362-D368. https://doi.org/10.1093/nar/gkw937

Szoke, E. and Gerich, J. E. 2005. Role of impaired insulin secretion and insulin resistance in the pathogenesis of type 2 diabetes mellitus. Comprehensive Therapy 31:106-112. https://doi.org/10.1007/s12019-005-0005-y

Turetschek, R., Staudinger, C., and Wienkoop, S. 2020. Rhizobial symbiosis influences response to early salt and drought stress of the Medicago truncatula root pro- teome. The Model Legume Medicago truncatula 253-260. https://doi.org/10.1002/9781119409144.ch31

Uchiki, T., Weikel, K. A., Jiao, W., Shang, F., Caceres, A., Pawlak, D., Handa, J. T., Brownlee, M., Nagaraj, R., and TayIor, A. 2012. Glycation-altered proteolysis as a pathobiologic mechanism that links dietary glycemic index, aging, and age-related disease (in nondiabetics). Aging Cell 11:113. https://doi.org/10.1111/j.1474-9726.2011.00752.x

Ummenhofer, C. C. and Meehl, G. A. 2017. Extreme weather and climate events with ecological relevance: a review. Philosophical Transactions of the Royal Society B: Biological Sciences 372(1723):20160135. https://doi.org/10.1098/ rstb.2016.0135

Uribarri, J., Cai, W., Sandu, O., Peppa, M., Goldberg, T., and Vlassara, H. 2005. Diet-derived advanced glycation end products are major contributors to the body's AGE pool and induce inflammation in healthy subjects. Annals of the New York Academy of Sciences 1043:461-466. https:// doi.org/10.1196/annals.1333.052

Verslues, P.E., Agarwal, M., Katiyar-Agarwal, S., Zhu, J., and Zhu, J.-K. 2006. Methods and concepts in quantifying resistance to drought, salt and freezing, abiotic stresses that affect plant water status. Plant Journal 45:523-539. https://doi.org/10.1111/j.1365-313X.2005.02593.x 